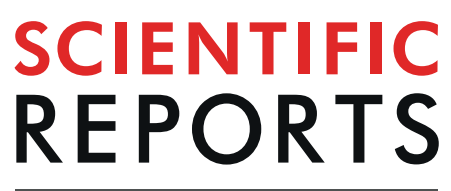

natureresearch

Published online: 14 April 2020

\title{
Publisher Correction: An optimized workflow for single-cell transcriptomics and repertoire profiling of purified lymphocytes from clinical samples
}

Richa Hanamsagar, Timothy Reizis, Mathew Chamberlain, Robert Marcus, Frank O. Nestle, Emanuele de Rinaldis \& Virginia Savova

Correction to: Scientific Reports https://doi.org/10.1038/s41598-020-58939-y, published online 10 February 2020

The original version of this Article contained an error in Affiliation 1, which was incorrectly given as 'Sanofi Immunology and Inflammation Research Therapeutic Area, 270 Albany St, Cambridge, MA, 02139, England'.

The correct affiliation is listed below:

Sanofi Immunology and Inflammation Research Therapeutic Area, 270 Albany St, Cambridge, MA, 02139, USA.

This error has now been corrected in the HTML and PDF versions of the Article.

(1) Open Access This article is licensed under a Creative Commons Attribution 4.0 International License, which permits use, sharing, adaptation, distribution and reproduction in any medium or format, as long as you give appropriate credit to the original author(s) and the source, provide a link to the Creative Commons license, and indicate if changes were made. The images or other third party material in this article are included in the article's Creative Commons license, unless indicated otherwise in a credit line to the material. If material is not included in the article's Creative Commons license and your intended use is not permitted by statutory regulation or exceeds the permitted use, you will need to obtain permission directly from the copyright holder. To view a copy of this license, visit http://creativecommons.org/licenses/by/4.0/.

(C) The Author(s) 2020 